\title{
Primjena aktivnog učenja temeljenog na aktivnostima promatranja $i$ bilježenja opažanja na primjeru mikroskopiranja papučice, Paramecium sp.
}

\author{
Mirela Sertić Perić1, Ana Marija Matić1, Darinka Kiš-Novak², Goran Vignjević ${ }^{3}$, Irena Labak ${ }^{3}$ \\ ${ }^{1}$ Sveučilište u Zagrebu, Prirodoslovno-matematički fakultet, Biološki odsjek, Zagreb, Hrvatska \\ mirela.sertic.peric@biol.pmf.hr \\ 2 Sveučilište u Zagrebu, Učiteljski fakultet, Odsjek u Čakovcu, Čakovec, Hrvatska \\ ${ }^{3}$ Sveučilište Josipa Jurja Strossmayera u Osijeku, Odjel za biologiju, Osijek, Hrvatska
}

\begin{abstract}
SAŽETAK
Primjenom metoda aktivnog učenja izbjegava se prenošenje gotovih činjenica i zaključaka te se znanja stječu kroz rješavanje izazova i problema. Aktivno učenje često podrazumijeva samostalno istraživanje, uključujući aktivnosti promatranja, bilježenja opažanja i zaključivanja temeljem opaženog. Na taj način povećava se intelektualni angažman studenata $i$ učenika, kao i vjerojatnost da će stečena znanja studenti i učenici uspješno primijeniti na nove izazove, bilo u radnom okruženju ili u drugim životnim situacijama. Efikasnost aktivnih metoda učenja, između ostalog, često ovisi i o kontekstu problema koji je predstavljen učenicima/studentima te o interesu učenika i/ili studenata za pojedine aktivnosti koje se primjenjuju u nastavi. $U$ ovom radu predstavljen je primjer primjene aktivnih metoda učenja, temeljenih na aktivnostima promatranja i bilježenja opažanja tijekom mikroskopiranja različitih preparata papučice, Paramecium sp., među studentima druge godine preddiplomskog studija različitih studijskih programa biologije i studentima učiteljskog fakulteta. Uz radni list, koji može poslužiti kao osnova za planiranje i prilagodbu nastavnih aktivnosti na nekoj drugoj razini obrazovanja, u ovom radu su iznijeti i komentari studenata nakon provedbe aktivnih metoda učenja temeljenih na mikroskopiranju papučice. Komentari studenata o primjeni aktivnih metoda učenja (u usporedbi s tradicionalnim metodama, koje se inače koriste u njihovoj redovnoj praktikumskoj nastavi) pružaju uvid u opći dojam studenata o doživljaju nastave i pojedinih aktivnosti koje se primjenjuju u nastavi te o učinku primijenjenih aktivnosti na razumijevanje sadržaja koji se poučavaju. Prema većini ispitanika u ovom radu, aktivne metode učenja su zanimljive i većina studenata se izjašnjava da u načelu "voli takve aktivnosti“, koje uključuju samostalan rad i zaključivanje. Takvo mišljenje studenata moglo bi poslužiti kao svojevrsni poticaj za intenzivniju primjenu metoda aktivnog učenja na fakultetskoj razini obrazovanja te da bi metode aktivnog učenja postupno trebale zamijeniti frontalnu nastavu i tradicionalne metode.
\end{abstract}

Ključne riječi: prirodoslovna pismenost; učenje otkrivanjem; opažačke sposobnosti; zapis učenika; praživotinje

\section{UVOD}

Efikasnost različitih metoda poučavanja ovisi o interesu učenika (studenata) za pojedine aktivnosti koje se primjenjuju u nastavi te o učinku primijenjenih aktivnosti na razumijevanje sadržaja koji se poučavaju (Swarat i sur, 2012). Primjenom metoda aktivnog učenja (u usporedbi s frontalnom nastavom i tradicionalnim metodama) učenik postaje aktivni subjekt u nastavnom procesu, umanjuje se predavačka funkcija učitelja, uspostavlja se interakcija između učitelja i učenika te se otvara prostor za samostalne aktivnosti učenika koje pomažu u kvalitetnijem usvajanju nastavnih sadržaja (Modell, 1996; Labak i sur, 2013). U metodama aktivnog učenja (npr. učenja otkrivanjem) nastoji se maksimalno izbjeći prenošenje gotovih činjenica i zaključaka te se podrazumijeva da učenik stječe znanje kroz rješavanje postavljenih mu izazova i problema, pri čemu samostalno istražuje (promatra, bilježi opažanja, zaključuje) (Bognar i Matijević, 2005; Boras, 2009; Garašić i sur., 2010; Podrug, 2017). Na taj način povećava se intelektualni angažman učenika i vjerojatnost da će stečena znanja uspješno primijeniti na nove izazove, u školskom okruženju ili u svakodnevnom životu (Bognar i Matijević, 2005).

Promatranje i bilježenje opažanja su temelj iskustvenog i istraživačkog učenja te učenja otkrivanjem na svim razinama biološkog obrazovanja (Norris, 1984, 1985). Pažljivim promatranjem i bilježenjem svojih

Sertić Perić, M., Matić, A.M., Kiš-Novak, D., Vignjević, G., Labak, I. (2019). Primjena aktivnog učenja temeljenog na aktivnostima promatranja i bilježenja opažanja na primjeru mikroskopiranja papučice, Paramecium sp. Educ. biol., 5:3447. URL DOI: https://doi.org/10.32633/eb.5.3 
opažanja, učenik stječe svojevrsno perceptivno iskustvo, odnosno osnovu za kritičko promišljanje o promatranim objektima, pojavama i/ili procesima (Norris, 1984, 1985). Upravo je stjecanje takvih vještina i iskustava osnova prirodoslovne pismenosti, koja podrazumijeva izvođenje zaključaka temeljenih na promatranju, opažanju i dokazima. Poticanje promatranja i bilježenja opažanja korisno je ne samo za razvoj prirodoslovne pismenosti, veći i za lakše donošenje odluka u brojnim životnim izazovima - od osobnog razvoja do društvene i poslovne odgovornosti (Dujmović, 2011; Braš Roth i sur, 2017). Stoga je jedna od ključnih uloga učitelja i nastavnika prirode i biologije poticati razvoj ovih vještina kod svojih učenika.

Opažačke sposobnosti sastoje se od triju vještina: vještina kvalitetnog promatranja, vještina zapisa opažanja i vještina samoprocjene vlastita zapisa (Norris, 1984). Premda su ove tri vještine u načelu različite, dobra samoprocjena zapisa opažanja pomaže da opažač kvalitetnije opaža i primjećuje detalje (Norris, 1984; Eberbach i Crowley, 2009). Tradicionalno, u prirodoslovnim edukacijskim programima smatralo se kako je za temeljito opažanje potrebno samo dobro promatrati objekt te ga istinito $i$ objektivno opisati. Kasnije je ipak prihvaćeno da je u pravom znanstvenom smislu potrebno oprezno, precizno i promišljeno promatrati objekt, a opažanja povezivati s dosadašnjim znanjem i stavljati ih u okvir znanstvenog područja o kojemu se govori (Norris, 1984; Eberbach i Crowley, 2009). Kako bi se kvalitetno razvile vještine promatranja, promatrač ne smije dopustiti emocijama da utječu na njegovu prosudbu, promatrani objekt treba uzeti u obzir kao cjelinu unutar zadanog konteksta i poželjno je imati temeljna teorijska znanja o promatranom objektu (Eberbach i Crowley, 2009). Također, prije promatranja treba osigurati da se minimaliziraju mogući utjecaji i popratne okolnosti poput: unaprijed znanog ishoda opažanja (pojave ili pokusa), vremena promatranja te kvalitete promatranog preparata i/ili mjernih instrumenata (Norris, 1984).

Kvalitetno razvijanje vještine bilježenja opažanja može se osigurati vježbom. Kako bi zapis opažanja bio što kvalitetniji, dobro ga je izraditi tijekom promatranja ili neposredno nakon (ali u istom okruženju u kojemu se odvijalo promatranje). Tijekom bilježenja, promatrač ne smije primati nove i dodatne informacije o promatranom objektu te mu se treba osigurati dovoljno vremena za zapis. Isto tako, zapis opažanja može sadržavati naknadno zabilježena dodatna opažanja koja promatrač isprva nije opazio, ali ih kasnije ističe u svom zapisu kao „naknadna opažanja“ (Norris, 1984). Može se navesti nekoliko koristi od vođenja bilješki tijekom promatranja. Za početak, bilješke služe da promatrač ne zaboravi što je promatrao. Procesom kreiranja zabilješki, promatračeve misli postaju fokusirane i jasne te se sam promatrač lakše usredotočuje na detalje i daljnje promatranje. Također, bilježenje opažanja promiče povezivanje opaženih detalja te oblikovanje zaključka, odnosno povezivanje teorijskog znanja i dokaza koje promatrač prikuplja (Garcia-Milla i Andersen, 2007).

U ovom radu predstavljen je primjer primjene aktivnih metoda učenja, temeljenih na aktivnostima promatranja i bilježenja opažanja tijekom mikroskopiranja različitih preparata papučice, Paramecium sp., među studentima druge godine preddiplomskog studija različitih studijskih programa biologije i studentima učiteljskog fakulteta. Uz radni list (prilog 1), koji može poslužiti kao osnova za planiranje i prilagodbu nastavnih aktivnosti na nekoj drugoj razini obrazovanja, u ovom radu su iznijeti i komentari studenata nakon provedbe aktivnih metoda učenja (mikroskopiranja papučice) usmjerenih na izvođenje zaključaka o karakteristikama i životu papučice temeljem promatranja različitih mikroskopskih preparata papučice i bilježenja vlastitih opažanja. Komentari studenata (prilog 3) o primjeni aktivnih metoda učenja ( $u$ usporedbi s tradicionalnim metodama, koje se inače koriste $u$ njihovoj redovnoj praktikumskoj nastavi) omogućuju uvid u opći dojam studenata o doživljaju nastave 
i pojedinih aktivnosti koje se primjenjuju u nastavi te o učinku primijenjenih aktivnosti na razumijevanje sadržaja koji se poučavaju. Uvid u dojam studenata o primjeni metoda aktivnog učenja (u usporedbi s frontalnom nastavom i tradicionalnim metodama) nadalje može olakšati planiranje nastave, kvalitetniju interakciju između učitelja (predavača) i učenika (studenta) kao i osmišljavanje svrsishodnijih samostalnih aktivnosti učenika i studenata, koje pomažu u kvalitetnijem usvajanju nastavnih sadržaja.

\section{METODE}

U ovom radu, primjena aktivnih metoda učenja temeljenih na aktivnostima promatranja i bilježenja opažanja osmišljena je na primjeru mikroskopiranja papučice, Paramecium sp. Kao modelni organizam za promatranje je odabrana papučica, Paramecium sp., zbog dostupnosti, jednostavnog uzgoja, rukovanja i pripreme preparata za promatranje, ali i zbog toga što su papučice obavezan dio učenja i praktikumskog rada na visokim učilištima koja su sudjelovala u ovom istraživanju. Papučice korištene u ovom radu uzgojene su na Zoologijskom zavodu Biološkog odsjeka Prirodoslovno-matematičkog fakulteta Sveučilišta u Zagrebu. U provedbi aktivnosti sudjelovalo je ukupno 114 studenata s tri različite institucije: 1) studenti Učiteljskog fakulteta Odsjeka u Čakovcu, 2) studenti biologije s Biološkog odsjeka Prirodoslovno-matematičkog fakulteta Sveučilišta u Zagrebu, 3) studenti biologije Odjela za biologiju Sveučilišta Josipa Jurja Strossmayera u Osijeku (ukupno: 50 studenata biologije, SB i 64 studenata učiteljskog fakulteta, SU). Među studentima biologije, aktivnosti obuhvaćene ovim radom su provedene u sklopu redovne praktikumske nastave na Biološkom odsjeku Prirodoslovnomatematičkog fakulteta Sveučilišta u Zagrebu i na Odjelu za biologiju Sveučilišta Josipa Jurja Strossmayera u Osijeku tijekom ljetnog semestra 2018. godine, a među studentima predškolskog odgoja i učiteljskog studija u sklopu ciljane radionice provedene na Učiteljskom fakultetu Odsjeka u Čakovcu u studenom 2018. godine. Sudionici su imali 90 minuta za provedbu aktivnosti promatranja, opažanja i bilježenja opažanja tijekom mikroskopiranja papučice te su i praktikumska nastava i radionica vođeni na isti način - prema uputama strukturiranog radnog lista. Ispitanici su dobili strukturirane radne listove s detaljnim uputama za rad i zadatcima (prilog 1), koje su ispunjavali individualno, ali je rad - zbog dostupnosti opreme (mikroskopa) - organiziran kao grupni rad (studenti učiteljskog fakulteta) ili individualni rad (studenti biologije). Tako je svaki student biologije papučicu promatrao zasebno, dok su studenti učiteljskog fakulteta mikroskopirali u grupama od po najviše pet sudionika (sudionici grupe su promatrali i bilježili opažanja zasebno, ali su se izmjenjivali na jednom mikroskopu unutar grupe). Primijenjeni radni list se nalazi u prilogu 1.

Studenti su bilježili opažanja promatrajući papučicu kako se slobodno pokreće (prva skupina zadataka) i kako se pokreće na preparatu na koji je stavljen komadić vate, čije su niti predstavljale svojevrsne „prepreke“ za papučice (druga skupina zadataka). Cilj promatranja slobodno pokretnih papučica i papučica s komadićem vate bio je uočiti i zabilježiti stanične strukture papučice vidljive na neobojenim preparatima te opisati način njihovog pokretanja u uvjetima bez i s „preprekama“ (nitima vate). Treća skupina zadataka obuhvaćala je pitanja vezana uz promatranje papučica obojenih kiselim metilenskim zelenilom (slika 1A). Cilj promatranja papučica tretiranih kiselim metilenskim zelenilom bio je uočiti i zabilježiti stanične strukture papučice, koje postaju vidljive primjenom kisele boje. Ujedno, bilo je važno opaziti kako papučica reagira u stresnim uvjetima tj. pri promjeni kiselosti $(\mathrm{pH})$ medija u kojem boravi. Četvrta skupina zadataka bila je vezana uz papučice kojima je dodana hranjiva otopina (mlijeko) i boja kongo-rot (slika 1B). Cilj ovog promatranja bio je opaziti promjene unutar papučice tijekom njenog probavnog procesa (tzv. cikloze). Peta skupina zadataka obuhvaćala je promatranje papučice tretirane metodom srebrne impregnacije (slika 1C). Cilj je bio zaključiti koje strukture u papučice 
postaju vidljive primjenom metode srebrne impregnacije te čemu opažene strukture služe u životu papučice. Na radnom listu je stajao kratki opis tretiranja papučica te su se ispod teksta nalazila potpitanja koja vode sudionike u tijek promatranja preparata.

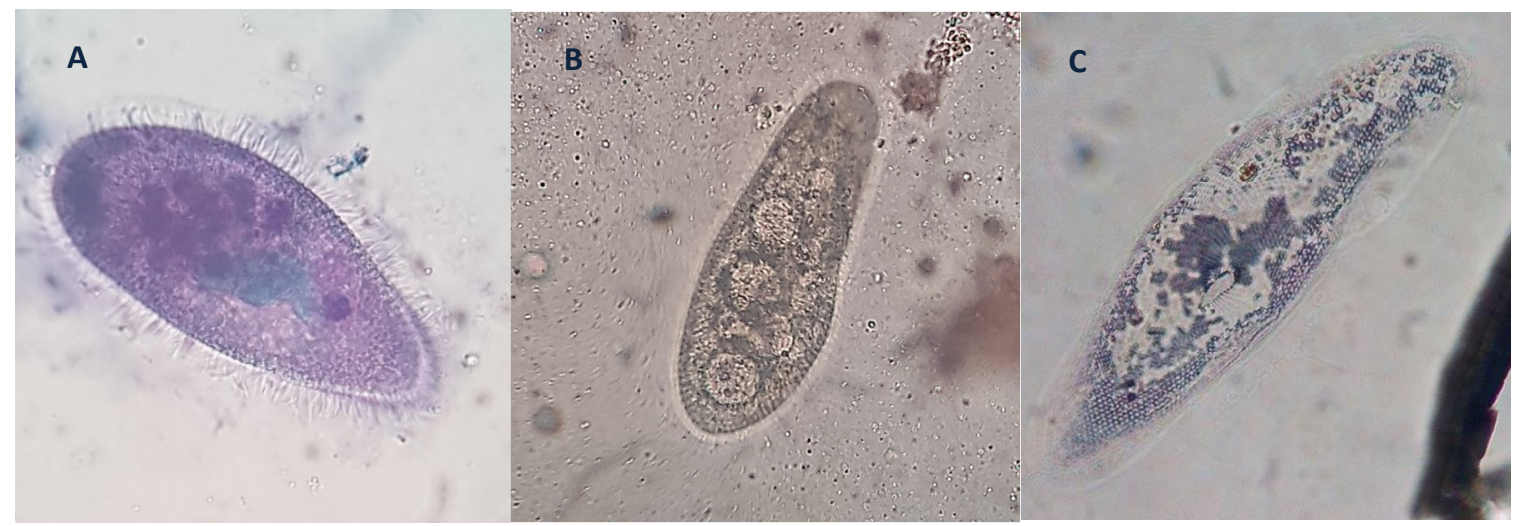

Slika 1 Fotografija A - papučice obojene kiselim metilenskim zelenilom; B - papučice u čiju je kulturu dodana kongo-rot boja i mlijeko (vidljivi hranidbeni mjehurići); C - trajnog preparata papučice tretirane metodom srebrne impregnacije (foto: Ana Marija Matić, 2019)

Nakon aktivnosti provedenih prema strukturiranom radnom listu, studenti su proveli raspravu o svojim opažanjima, bilješkama i zaključcima s voditeljem praktikumske nastave/radionice te su temeljem rasprave izvedeni zajednički zaključci o karakteristikama i životu papučice. Po provedbi svih nastavnih aktivnosti, proveden je kratki upitnik (prilog 2) s ukupno pet pitanja (tri pitanja zatvorenog i dva pitanja otvorena tipa), kojim se nastojalo procijeniti koliko su studenti bili upućeni u tematiku praživotinja prije provođenja opisanih aktivnosti, kao i osobni dojam studenata o načinu rada temeljenog na promatranju i bilježenju vlastitih opažanja te naknadnom donošenju zaključaka. Odgovori na pitanja otvorenog tipa specifično su kodirani s obzirom na odgovore sudionika primjenom metodologije prema Radanović i sur. (2016). Specifičnim kodiranjem se svakom odgovoru dodijelio odgovarajući kod, odnosno odgovor koji objedinjuje više različitih, a u osnovi istih odgovora (kod koji više različitih odgovora svodi na zajednički nazivnik).

\section{REZULTATI}

Prema odgovorima na pitanja u kratkom upitniku (prilog 2), koji su studenti ispunjavali nakon provedbe aktivnosti, većina studenata ( $94 \%$ SB i $95 \%$ SU) je prije provedenih aktivnosti s papučicom odslušala predavanje o jednostaničnim organizmima/trepetljikašima. Na pitanje jesu li ikada prije provedenih aktivnosti mikroskopirali trepetljikaše, studenti su također većinski potvrdno odgovorili (96 \% SB i 66 \% SU). U trećem pitanju upitnika, od studenata se zahtijevalo da navedu koje su strukture u građi trepetljikaša prvi puta upoznali za vrijeme provođenja istraživanja. Odgovori su specifično kodirani (tablica 1). Studenti biologije u najvećem postotku (39 \%) tvrde da im je sve poznato od prije, dok studenti učiteljskog fakulteta u najvećem postotku (15\%) nisu dali odgovor na postavljeno pitanje. U podjednakom postotku tvrde da su prvi puta čuli za trepetljike (13\%), bazalna tjelešca (12\%), probavne mjehuriće (11 \%) i stanična usta (9\%). Studenti biologije su isto tako naveli da su prvi put čuli za trepetljike na staničnim ustima, kinetide ili pelikulu (20\%) i trihociste (22 \%) (slika 2).

U četvrtom pitanju upitnika, $91 \%$ studenata učiteljskog fakulteta i $84 \%$ studenata biologije izjasnilo se da im nije bilo teško pratiti sadržaje praktikuma prema zadanoj strukturi, dok $16 \%$ studenata biologije i 9 \% studenata učiteljskog fakulteta tvrdi da im je bilo teško pratiti istraživanje i mikroskopiranje papučice. 
Tablica 1 Opis specifičnih kodova za treće pitanje upitnika (Koje strukture u staničnoj građi trepetljikaša ste se po prvi puta upoznali upravo na današnjem praktikumu (tj. za koje strukture papučice ranije niste znali)? (NAPIŠITE S OBZIROM NA OSOBNA ISKUSTVA) upućenog studentima biologije i studentima učiteljskog fakulteta nakon mikroskopiranja papučica

\begin{tabular}{|l|c|}
\hline Opis specifičnog koda & Specifični kod \\
\hline Sve je poznato od prije (iz srednje škole i slično) & SK_1 \\
\hline Sve strukture su nove & SK_2 \\
\hline Nema odgovora & SK_3 \\
\hline Bazalna tjelešca (kinetosom) & SK_4 \\
\hline Trihociste & SK_5 \\
\hline Probavni mjehurići & SK_6 \\
\hline Stanična usta / citosom & SK_7 \\
\hline "Želudac" & SK_8 \\
\hline Makronukleus i/ili mikronukleus / jezgra & SK_9 \\
\hline Trepetljike (na staničnim ustima) / kinetide / pelikulu & SK_10 \\
\hline U odgovoru nisu navedene strukture nego postupci bojanja papučica & SK_11 \\
\hline U odgovoru nisu navedene strukture nego ponašanje papučice & SK_12 \\
\hline U odgovoru nisu navedene strukture nego samo da je prikazana detaljno & SK_13 \\
\hline
\end{tabular}

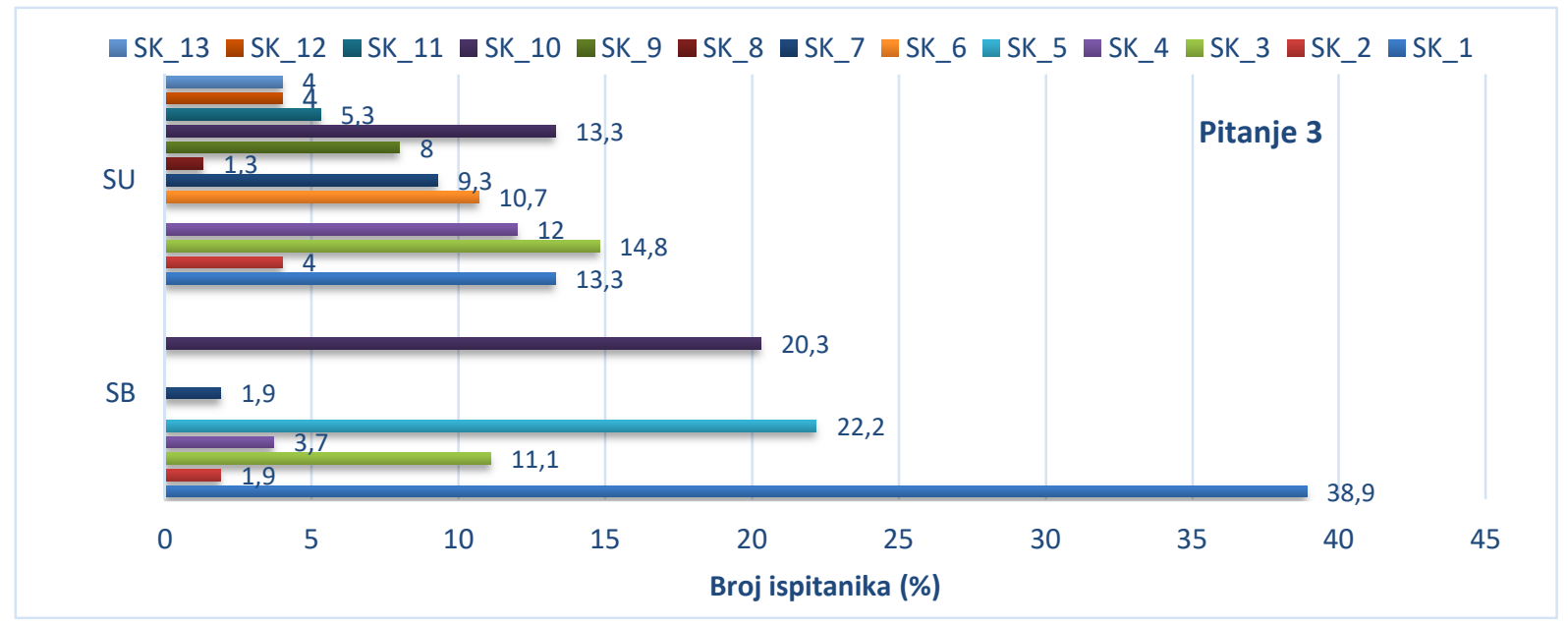

Slika 2 Odgovori studenata biologije (SB) i učiteljskog fakulteta (SU) na treće pitanje upitnika (Koje strukture u staničnoj građi trepetljikaša ste se po prvi puta upoznali upravo na današnjem praktikumu (tj. za koje strukture papučice ranije niste znali)? (NAPIŠITE S OBZIROM NA OSOBNA ISKUSTVA)). Opisi specifičnih kodova (SK) odgovora studenata nalaze se u tablici 1

U petom pitanju traženo je od studenata da napišu zašto im se je ili nije svidio način rada mikroskopiranja, bilježenja opažanja i samostalnog donošenja zaključaka. $U$ tablici 2 nalazi se opis specifičnih kodova za peto pitanje ankete, a na slici 5 prikazana je analiza tih odgovora po skupinama ispitanika. Oko 31 \% studenata učiteljskog fakulteta tvrdi da im se svidio način rada, jer je bilo zanimljivo i jer vole takve vježbe, a $26 \%$ studenata biologije razlog pronalazi u tome, jer im je sve bilo poznato od prije. Dok $18 \%$ studenata biologije tvrdi da im se nije svidio ovakav način rada, zbog nedostatka informacija i nepoznavanja struktura koje su trebali opaziti, njih $24 \%$ tvrdi da im se svidio način rada jer su prethodno odslušali predavanje ili su pisali kolokvij. Gotovo $16 \%$ studenata učiteljskog fakulteta tvrdi da im se svidio način rada, jer je rad bio dobro organiziran, sve je bilo objašnjeno te je profesorica bila zanimljiva. $5 \%$ studenata biologije tvrdi da im je bilo lako pratiti mikroskopiranje i zadatke, jer se iz teksta zadatka mogao izvući odgovor (slika 3). Osim navedenog, primijećeno je kako su studenti biologije u praznom prostoru upitnika dali dodatne i detaljnije informacije o tome što je bilo dobro, a što je bilo loše, kao i konstruktivne kritike na račun organiziranja i provođenja mikroskopiranja i promatranja papučica prema strukturiranom radnom listu. Odgovori studenata na 5. pitanje, kao i sva dodatna studentska opažanja i kritike na način rada iznijeti su u prilogu 3. 
Tablica 2 Opis specifičnih kodova za peto pitanje upitnika (Zašto vam se je/nije svidio način rada s današnjeg praktikuma? (NAPIŠITE S OBZIROM NA OSOBNA ISKUSTVA)) upućenog studentima biologije i studentima učiteljskog fakulteta nakon mikroskopiranja papučica

\begin{tabular}{|c|c|}
\hline Opis specifičnog koda odgovora ispitanika & Specifični kod \\
\hline Zato što je sve je poznato od prije (iz srednje škole/drugo). & SK_1 \\
\hline Nema odgovora i/ili navedeno je samo da je/nije bilo teško pratiti. & SK_2 \\
\hline Zbog toga što su prethodno odslušali predavanje i/ili pisali kolokvij. & SK_3 \\
\hline „Zato što je bilo zanimljivo i/ili poučno" / „zato što volim takve vježbe“. & SK_4 \\
\hline „Zato što se iz postavljenog zadatka mogao izvući odgovor“. & SK_5 \\
\hline „Zato što je sve bilo dobro objašnjeno / organizirano / profesorica je zanimljiva“. & SK_6 \\
\hline $\begin{array}{l}\text { "Zato što je teško mikroskopom pronaći papučicu / mikroskop nije radio / nemam iskustva s } \\
\text { mikroskopiranjem". }\end{array}$ & SK_7 \\
\hline „Zbog nedostatka znanja“. & SK_8 \\
\hline Zbog toga što su sami promatrali detalje / sami su mikroskopirali & SK_9 \\
\hline Zato što nisu znali na što obratiti pažnju / koje strukture promatrati (zbog nedostatka informacija). & SK_10 \\
\hline „Zbog jednostavnosti promatranog organizma." & SK_11 \\
\hline
\end{tabular}

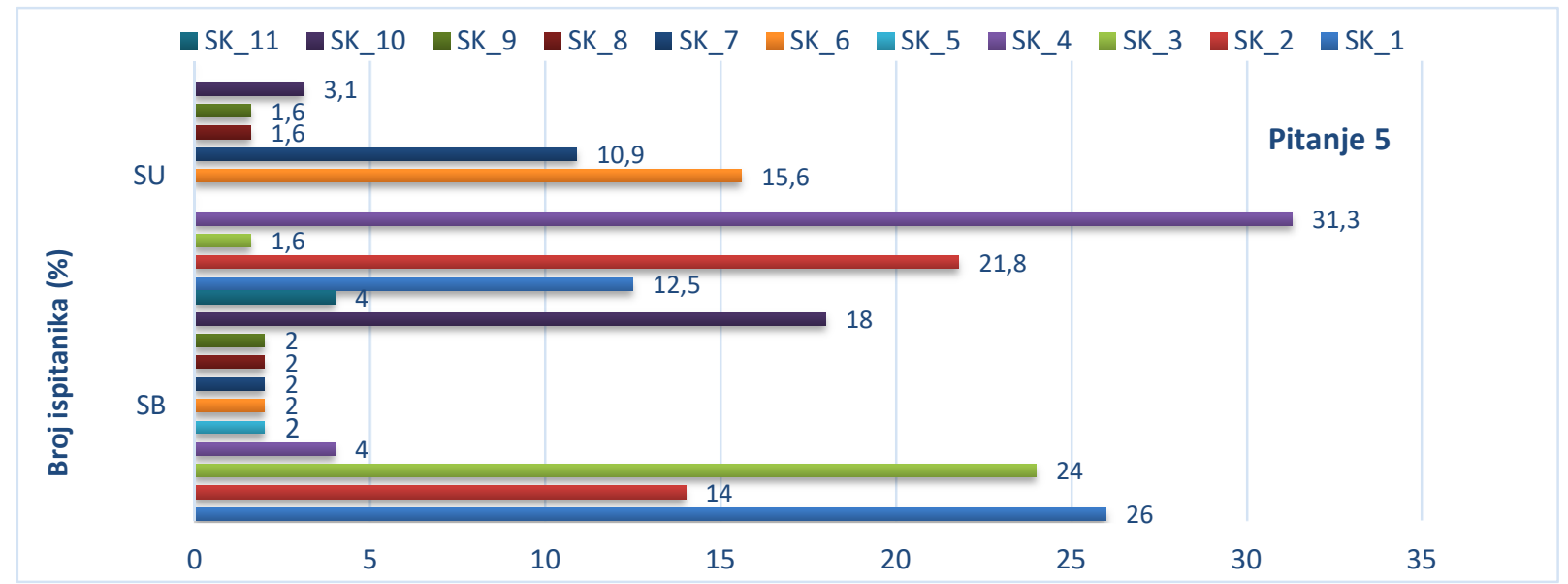

Slika 3 Odgovori studenata biologije (SB) i učiteljskog fakulteta (SU) na peto pitanje upitnika (Zašto vam se je/nije svidio način rada s današnjeg praktikuma? (NAPIŠITE S OBZIROM NA OSOBNA ISKUSTVA)). Opisi specifičnih kodova (SK) odgovora studenata nalaze se $u$ tablici 2

\section{RASPRAVA}

Vjerodostojno znanstveno opažanje složen je i izazovan pothvat usko vezan uz određenu struku i/ili područje istraživanja, a nužno uključuje promatranje i bilježenje opažanja (Norris, 1984, 1985; Eberbach i Crowley, 2009). Istančane vještine promatranja te ilustriranja i opisivanja opažajnih objekata doprinose opažanju detalja i donošenju znanstveno ispravnih i/ili ispravnijih zaključaka (Norris, 1984, 1985). Stoga aktivne metode učenja, koje naglašavaju značaj zaključivanja temeljem promatranja i bilježenja opažanja, nisu poželjne samo tijekom osnovnoškolskog i srednjoškolskog obrazovanja, već bi trebale biti osnova za poučavanje biologije i na fakultetskoj razini, gdje bi se studente trebalo potaknuti da uz osnovno opažanje tijekom praktičnog rada razmišljaju o procesima i međuodnosima koji su rezultat pojedinih opaženih struktura i pojava.

Fakultetska nastava studenata bioloških usmjerenja većine kolegija se, osim tradicionalnih, frontalnih predavanja, odvija u praktikumima gdje studenti imaju prilike samostalno mikroskopirati, secirati i/ili pripremati biološke preparate te, promatrajući ih, učiti različite biološke koncepte. Mikroskopiranje i promatranje bioloških preparata je studentima biologije gotovo svakodnevnica te im ono ne predstavlja problem, kao što je vidljivo i iz njihovih odgovora u upitniku. Također, analizom odgovora studenata biologije utvrđeno je kako su za većinu struktura čuli prije provođenja zadane aktivnosti te im stoga nije bilo teško pratiti strukturirani radni list i zaključivati temeljem promatranja mikroskopskih preparata. Lakoća kojom studenti biologije pristupaju rješavanju radnog lista tijekom promatranja 
papučice u ovom radu vjerojatno je rezultat kontinuirane izloženosti tih studenata biološkim sadržajima, metodama i aktualnostima, koja je u redovnoj fakultetskoj nastavi prirodoslovlja studenata Učiteljskog fakulteta zastupljena u manjoj mjeri. Međutim, studenti Učiteljskog fakulteta također u najvećem postotku izjavljuju da nemaju poteškoća u svladavanju zadanih aktivnosti tijekom mikroskopiranja papučice, vjerojatno zato što su ipak stekli dostatna iskustva u mikroskopiranju i bilježenju opažanja tijekom svoje fakultetske nastave i/ili dotadašnjeg obrazovanja. Vjerojatno iz istog razloga (zbog razlika u izloženosti biološkim sadržajima), studenti biologije u najvećem postotku samouvjereno tvrde da im je većina pojmova uvedena tijekom opisanih aktivnosti poznata od prije, dok studenti Učiteljskog fakulteta u najvećem postotku nisu dali odgovor na to pitanje. Moguće je da studenti Učiteljskog fakulteta u upitniku nisu željeli priznati stvarno stanje (tj. nisu spremni dati odgovor na ovo pitanje iz bojazni da bi ih iskreni odgovor možda predstavio u negativnom svjetlu vezano uz sudjelovanje na nastavi), premda je moguće i da su prethodno tijekom svog srednjoškolskog školovanja već upoznali sve promatrane strukture pa ih zato ne navode u odgovoru.

Nekolicina studenata u ovom istraživanju ističe da preferiraju kada praktičnom radu (mikroskopiranju) prethode teorijski uvod i detaljna pojašnjenja o tome što će se promatrati, jer ih takav pristup jasnije usmjerava na što treba obratiti pažnju tijekom praktičnog rada, što im ujedno olakšava shvaćanje predavanog gradiva. Međutim, relativno velikom broju studenata se svidio provedeni način rada, gdje su tradicionalne metode zamijenjene aktivnim metodama. $U$ tradicionalnim metodama detaljno tumačenje pojmova i/ili pojava prethodi promatranju i prepoznavanju tumačenih pojmova i/ili pojava na objektima iz žive stvarnosti, dok u aktivnim metodama samostalno promatranje i bilježenje opažanja prethodi raspravi popraćenoj tumačenjem opaženih pojmova i/ili pojava i zaključivanjem (Bognar i Matijević, 2005). Budući da se velik broj studenata u ovom radu izjašnjava da u načelu „voli takve vježbe" (vježbe samostalnog promatranja i bilježenja opažanja nakon kojih slijedi tumačenje opaženih pojmova), može se zaključiti da su aktivne metode učenja studentima općenito zanimljive. Međutim, potrebno je naglasiti da su dob i prethodno iskustvo učenika i studenata vrlo važni u prihvaćanju aktivnih oblika rada (Serdyukov i Serdyukova, 2009). Aktivne metode potiču učenike i studente na uključivanje i razmišljanje, a mnogima je vjerojatno lakše pasivno pratiti nastavu tradicionalnog oblika. Stoga se primjena aktivnog učenja treba vježbati i uvoditi od najmlađe učeničke dobi, jer ovisno o prijašnjem iskustvu sudionika nastave, kod starijih učenika i/ili studenata, može naići na veći ili manji otpor (prema Serdyukov i Serdyukova, 2009). Ako su učenici dugotrajno izloženi aktivnoj nastavi, naviknu se na nju i prihvaćaju je kao zanimljiv i dobar način učenja te će, što su stariji, vjerojatno teže prihvatiti promjene u vidu tradicionalnih metoda učenja.

Uvid u mišljenje studenata o aktivnim metodama unutar ovog istraživanja mogao bi poslužiti kao svojevrsni poticaj za primjenu metoda aktivnog učenja na fakultetskoj razini obrazovanja (u zamjenu s frontalnom nastavom i tradicionalnim metodama), koje bi potom zasigurno osigurale i kvalitetniju interakciju između predavača i studenta te bi doprinijele osmišljavanju svrsishodnijih samostalnih aktivnosti studenata, odnosno kvalitetnijem usvajanju nastavnih sadržaja i njihovoj transverabilnosti na druga područja (npr. na druge predmete slične problematike, životne izazove, edukaciju mlađih naraštaja, itd.). To je osobito važno pri edukaciji budućih učitelja i nastavnika, koji su odgovorni za razvoj kompetencija svojih učenika te se ne smije dogoditi da su i sami nedovoljno kompetentni za vještine koje traže od svojih učenika (Ćurić i sur, 2013). Odnosno, ako tražene vještine (npr. vještine zaključivanja temeljenog na promatranju, opažanju i bilježenju opažanja) nisu kvalitetno razvijene kod nastavnika, nastavnici neće moći poticati razvijanje istih vještina kod učenika (Borić i Runje, 2014). 
Iz naknadnog razgovora sa studentima-sudionicima ovoga rada, dodatno se dalo naslutiti da su neki zadatci radnog lista (prilog 1) nespretno sročeni i slabije kvalitete. Izgledno je da, prilikom strukturiranja radnog lista ponegdje nije dovoljno dobro precizirano što se točno od sudionika očekuje (npr. u zadatcima s crtežom, nije precizirano treba li crtež označiti ili ne pa su neki sudionici samo nacrtali objekt promatranja, bez pokušaja označavanja, jer se to u zadatku nije precizirano tražilo) te su stoga neki sudionici pokazali negodovanje.

Također, moguće je da je na razliku u dojmovima i detaljnijim komentarima između studenata biologije i Učiteljskog fakulteta utjecala i činjenica da je svaki student biologije imao na raspolaganju svoj mikroskop, dok su studenti Učiteljskog fakulteta mikroskopirali u grupama do pet sudionika. To je vjerojatno utjecalo na vrijeme koje je svaki student Učiteljskog fakulteta imao na raspolaganju za opažanje i bilježenje opažanja, a time i na kvalitetu promatranja i zapisa te na poteškoće u praćenju sadržaja aktivnosti, koje je potvrdilo $9 \%$ studenata Učiteljskog fakulteta. S druge strane, čak $16 \%$ studenata biologije iskazalo je poteškoće u praćenju sadržaja praktikuma temeljenog na aktivnim metodama učenja. Uzimajući u obzir specifične komentare studenata (prilog 3), može se zaključiti da je taj postotak posljedica subjektivnog umora studenata i/ili činjenice da studenti nisu navikli na ovaj način rada, zbog čega iskazuju negodovanje ako su primorani na samostalan rad i zaključivanje bez prethodnog tumačenja sadržaja koji se promatraju. Prema tome, prilikom uklapanja metoda aktivnog učenja u nastavu, osim samog sadržaja, potrebno je unaprijed detaljno planirati koji će se ciljevi, u kojoj mjeri i na koji način ostvariti, provjeriti i vrednovati (Grgurić i sur, 2017). U suprotnom, ako se ne obrati dovoljno pažnje na strukturiranje, smisao i svrhu zadataka i/ili uputa za rad, može se dogoditi da provjeravamo samo poznavanje pojedinih činjenica i podataka (Radanović i sur, 2017), što vjerojatno može djelomično utjecati i na zadovoljstvo ispitanika načinom rada. Osim toga, dobro je znati da se studentima tijekom promatranja treba često postavljati pitanja „Što?" i „Kako?", a osobito "Zašto?", jer ih se na taj način usmjerava na kvalitetniju izradu opažačkih zabilješki, ispravnije donošenje zaključaka i temeljenje učenja na traženju uzročno-posljedičnih veza (Mayr, 1997; Alberdi i sur., 2000). Postavljajući si navedena pitanja tijekom procesa promatranja, učenici i studenti kontinuirano usavršuju vještine opažanja i usmjeravaju bitna opažanja u znanstveno ispravan zaključak (Eberbach i Crowley, 2009). Prema odgovorima studenata na pitanja u radnom listu primijenjenom u ovom istraživanju, možemo zaključiti da na fakultetskoj razini obrazovanja (kod studenata), a vjerojatno i na nižim razinama obrazovanja (kod učenika različite dobi), konkretno pitanje u pravom trenutku može otvoriti neke drugačije poglede i dimenzije tijekom promatranja, opažanja, bilježenja opažanja istraživanja, zaključivanja $\mathrm{i}$ razumijevanja te tako poticati razvijanje prirodoslovne pismenosti. Međutim, neki odgovori studenata na pitanje „Zašto vam se je ili nije svidio način rada $s$ današnjeg praktikuma" (npr. odgovori SB_6, SB_48 u prilogu 3) upućuju da su studenti najviše usmjereni na operiranje činjenicama, što je vjerojatno velikim dijelom posljedica pretežito tradicionalne predavačke nastave bazirane na memoriranju detalja, zbog čega studenti traže informacije o predmetu promatranja prije samog promatranja kako su navikli tijekom godina učenja. Nasuprot tome, malobrojni odgovori (npr. odgovori SB_2 i SB_12 u prilogu 3) upućuju da neki studenti uviđaju koliko je važan samostalan rad uz zaključivanje tijekom učenja koje traži njihovu angažiranost i osvješćivanje kvalitete znanja te vodi boljem stjecanju novog znanja.

Važno je napomenuti da učenici i studenti nerijetko mogu steći krivu predodžbu o zadatku (i/ili relevantnoj znanstvenoj činjenici i/ili teoriji) temeljenom na promatranju pa ne uočavaju važnost $i$ korist bilježenja opažanja tijekom promatranja. Primjerice, može se dogoditi da učenici i studenti tijekom izvršenja nekog zadatka ne osvijeste važnosti i učinke učenja uz bilježenje promatranja te 
propuste povratnu informaciju nastavnika koja ih može potaknuti na usavršavanje njihovog znanja i vještina (Garcia-Mila i Andersen, 2007). Kako bi se učenike i studente potaknulo na znanstveno promatranje (postavljanje ciljanih pitanja usmjerenih na detaljno promatranje i bilježenje opažanja), uputno je da objekt ili pojava koji se promatraju budu u kontekstu problema koji je njima zanimljiv (Chinn i Malhotra, 2002), odnosno da motiviraju studenta/učenika na bilježenje opažanja i/ili da se osmisle zadatci u kojima je vođenje bilješki prijeko potrebno (budući da vođenje bilješki kod učenika i/ili studenata samo po sebi i nije najpoželjnija aktivnost). Zbog svega toga bi, u kontekstu ovog istraživanja, trebalo unaprijediti početni primjer radnog lista, kako bi se: (i) zadatcima dao veći smisao (posebno zadatcima vezanima uz promatranje obojenja); (ii) tražilo studente da sami zaključe o značaju promatranih struktura i razlozima zbog kojih su pojedine strukture vidljive uz određeni način prepariranja (npr. metilensko zelenilo i srebrna impregnacija); (iii) tražilo studente da povežu način pripreme preparata za promatranje (npr. miješanje kulture papučica s mlijekom obojenog crvenom kongo rot bojom) s procesom koji se odvija u promatranom organizmu (npr. cikloza).

\section{ZAKLUČAK I METODIČKI ZNAČAJ}

Rezultati ovog rada upućuju da primjena aktivnih metoda učenja temeljenih na promatranju i bilježenju vlastitih opažanja predstavlja koristan način rada za studente prirodoslovnih i bioloških usmjerenja te bi intenzivnija primjena ovakvih metoda u praksi vjerojatno rezultirala kvalitetnijim usvajanjem nastavnih sadržaja, u usporedbi s tradicionalnim metodama, koje se još uvijek najčešće koriste u redovnoj fakultetskoj praktikumskoj nastavi.

\section{LITERATURA}

Alberdi E., Sleeman D. H., Korpi M. (2000). Accommodating surprise in taxonomic tasks: The role of expertise. Cognitive Science, 21, 53-91.

Bognar L., Matjević M. (2005). Didaktika. Školska knjiga, Zagreb.

Boras M. (2009). Suvremeni pristupi nastavi prirode i društva. Život i škola, 21, 40-49.

Borić E., Runje M. (2014). Kompetencije studenata budućih učitelja za poučavanje sadržaja nastave prirode i društva. Suvremeni izazovi teorije i prakse odgoja i obrazovanja, 41-50.

Braš Roth M., Markočić Dekanić A., Markuš Sandrić M. (2017). PISA 2015. Prirodoslovne kompetencije za život. NCVVO, Zagreb.

Chinn C. A., Malhotra B. A. (2002). Epistemologically authentic inquiry in schools: A theoretical framework for evaluating inquiry tasks. Science Education, 86, 175-218.

Ćurić A., Prišl E., Anđić D. (2013). Osposobljavanje učitelja za poučavanje prirodnih znanosti u Hrvatskoj i Danskoj: usporedna analiza. Acta ladertina, 10, 11-23.

Dujmović I. (2011). Važnost praktičnog rada u ostvarivanju prirodoslovne pismenosti. Školski vjesnik: časopis za pedagogijsku teoriju i praksu, 60 (4).

Eberbach C., Crowley K. (2009). From everyday to scientific observation: How children learn to observe the biologist's world. Review of Educational Research, 79, 39-68.

Garašić D., Čačić Ž., Benović I., Lukša Ž., Radanović I. (2010). Utjecaj istraživačkog pristupa u nastavi na učenička postignuća. Edukacija prirodoslovlja, geografije i povijesti u društvu znanja, zbornik sažetaka, 29-29.

Garcia-Mila M., Andersen C. (2007). Developmental change in notetaking during scientific inquiry. International Journal of Science Education, 29, 1035-1058.

Grgurić I., Begić V., Bastić M., Lukša Ž., Radanović I. (2017). Kvaliteta pitanja i uspjeh srednjoškolskih sudionika natjecanja iz biologije u znanju. Educatio Biologiae 1, 32-56.

Labak I., Merdić E., Heffer M., Radanović I. (2013). Povezanost aktivnih strategija rada u pojedinačnom i blok-satu s usvojenošću nastavnog sadržaja biologije. Sociologija i prostor, 3, 509-521.

Mayr E. (1997). This is biology. The Belknap Press of Harvard University Press. Cambridge, MA.

Modell H. I. (1996). Preparing students to participate in an active learning environment. Advance in Physiology Education, 270, 69-77.

Norris S. P. (1984). Defining observational competence. Science Education, 68, 129-142.

Norris S. P. (1985). The philosophical basis for observation in science and science education. Journal of Research in Science Teaching, 22, 817-833.

Podrug I. (2017). Utjecaj primjene strategije učenje otkrivanjem na motivaciju učenika za učenje biologije na primjeru nastavne jedinice molekula DNA. Educatio Biologiae, 3, 143-158. 
Radanović I., Garašić D., Lukša Ž., Ristić-Dedić Z., Jokić B., Sertić Perić M. (2016). Understanding of photosynthesis concepts related to students' age. Electronic Proceedings of the ESERA 2015 Conference, 271-277.

Radanović I., Lukša Ž., Begić V., Gotlibović G., Kapov S., Pavunec S., Toljan M. (2017). Sadržajna i metodološka analiza ispita državne mature iz Biologije školskih godina 2013./2014. i 2014./2015. NCVVO, Zagreb.

Serdyukov P., Serdyukova N. (2009). A study of instructional practices: The case for reflection and research. Journal of Research in Innovative Teaching, 2, 193-210.

Swarat S., Ortony A., Revelle W. (2012). Activity matters: Understanding student interest in school science. Journal of Research in Science Teaching, 49, 515-537.

\section{PRILOZI}

Prilog 1 Radni list korišten pri mikroskopiranju papučice

GODINA STUDIJA:_ SMJER STUDIJA:_ VISOKO UČILIŠTE:

\section{A. Kretanje i ponašanje papučica}

Da bi ste promatrali slobodno kretanje papučica, pod mikroskopom pažljivo promatrajte kapljicu vode u kojoj žive papučice. Zabilježite svoja opažanja.

1A. Kako biste opisali kretanje papučice i njene pokrete?

1B. Mijenja li papučica (često) smjer prilikom kretanja?

1C. Je li papučica stalno 'u pokretu' ili ponekad i miruje i/ili zastajkuje? Što mislite zašto je tako?

1D. Nacrtajte kako je izgledala papučica pod mikroskopom.

Pod mikroskopom najprije pažljivo promotrite kapljicu vode u kojoj žive papučice. Budući da se papučice brzo kreću, teško je detaljnije promotriti njihov izgled. Stoga je dobro kapljicu vode u kojoj žive papučice kapnuti na komadić vate. Na taj način se može usporiti kretanje papučica i olakšati proučavanje njihovog izgleda. Zabilježite svoja opažanja.

2A. Opažate li više detalja na papučicama promatrajući papučice u kapljici bez vate ili koristeći vatu kao sredstvo za usporavanje? Zašto?

2B. Usporedite i opišite način kretanja papučice u kapljici bez vate i u kapljici s vatom.

2C. Što vam je zanimljivije promatrati - papučice u kapljici bez vate ili papučice u kapljici s vatom? Zašto?

2D. Nacrtajte kako je izgledala papučica u kapljici s vatom

\section{B. Obojene papučice}

Pojedini dijelovi papučica se bolje opažaju ako se mikroskopski preparati papučica oboje. Obojite papučice i otkrijte neke od 'skrivenih' dijelova papučice važnih za njen život!

\section{PAPUČICA OBOJENA KISELIM METILENSKIM ZELENILOM}

Pod mikroskopom najprije pažljivo promotrite kapljicu vode u kojoj žive neobojene papučice. Potom, pripremite drugi mikroskopski preparat, u kojem ćete kapljicu vode u kojoj žive papučice dodati na MALENU kapljicu zelene boje (kiselo metilensko zelenilo; KMZ). Pažljivo promatrajte preparate pod mikroskopom i zabilježite svoja opažanja.

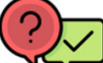

3A. Po čemu se papučice obojene KMZ-om razlikuju od neobojenih papučica.

3B. Što primjećujete na papučici obojenoj KMZ-om, a niste opazili na neobojenoj papučici?

3C. Što mislite, zašto papučica obojena KMZ-om izgleda drugačije od neobojene papučice?! Što je mogao biti uzrok promjena koje opažate? (odgovor je vaša slobodna pretpostavka tj. nema krivih odgovora tj. cijeni se što god da odgovorite tj. vaš odgovor se ne ocjenjuje)

3D. Nacrtajte kako pod mikroskopom izgleda papučica obojena KMZ-om.

PAPUČICA OBOJENA BOJOM KONGO ROT

Pod mikroskopom najprije pažljivo promotrite kapljicu vode u kojoj žive neobojene papučice. Potom, pripremite drug mikroskopski preparat, u kojem ćete na komadić vate kapnuti kapljicu vode u kojoj žive papučice i kapljicu mlijeka obojenog crvenom kongo rot (KR) bojom. Pažljivo promatrajte preparate pod mikroskopom i zabilježite svoja opažanja.

4A. Koje strukture vidite $u /$ na papučici obojenoj KR-om, a niste vidjeli u/na neobojenoj papučici? 
4B. Što mislite, što je to što vidite u/na papučicama obojenim KR-om? (odgovor je vaša slobodna pretpostavka tj. nema krivih odgovora tj. cijeni se što god da odgovorite tj. vaš odgovor se ne ocjenjuje)

4C. Što mislite, čemu služi mlijeko, u koje smo ubacili papučice? (odgovor je vaša slobodna pretpostavka tj. nema krivih odgovora tj. cijeni se što god da odgovorite tj. vaš odgovor se ne ocjenjuje)

4D. Nacrtajte kako papučica obojena KR-om izgleda pod mikroskopom.

\section{PAPUČICA OBOJENA METODOM SREBRNE IMPREGNACIJE}

Pod mikroskopom najprije pažljivo promotrite kapljicu vode u kojoj žive neobojene papučice. Potom, pod jačim povećanjem mikroskopa pažljivo promotrite trajni mikroskopski preparat papučica obojenih metodom srebrne impregnacije (MSI). Metoda srebrne impregnacije (MSI) svodi se na izlaganje mikroskopskih preparata nizu različitih otopina, kako bi se organizmi na preparatu postupno fiksirali, obojili pomoću srebrova nitrata, dehidrirali te sačuvali u svom izvornom obliku. Srebrov nitrat se tijekom postupka reducira i prelazi u elementarno srebro koje prožme (tj. impregnira) pojedine stanične strukture.

\section{A. Što vidite na papučici obojenoj pomoću MSI, a niste vidjeli na neobojenoj papučici?}

5B. Pokušajte pretpostaviti, koje stanične strukture su vidljive (impregnirane) na preparatu papučica obojenih pomoću MSI? (odgovor je vaša slobodna pretpostavka tj. nema krivih odgovora tj. cijeni se što god da odgovorite tj. vaš odgovor se ne ocjenjuje)

5C. Nacrtajte kako papučica obojena pomoću MSI izgleda pod mikroskopom.

Prilog 2 Upitnik koji su studenti ispunili nakon mikroskopiranja papučice

GODINA STUDIJA:_ SMJER STUDIJA:_ VISOKO UČILIŠTE:

1. Jeste li prije današnje vježbe $s$ papučicom prethodno odslušali predavanje o jednostaničnim organizmima/trepetljikašima?

DA

NE

(ZAOKRUŽITE VAŠ ODGOVOR)

2. Jeste li se prije današnje vježbe s papučicom susreli s promatranjem trepetljikaša/papučica?

DA

NE

(ZAOKRUŽITE VAŠ ODGOVOR)

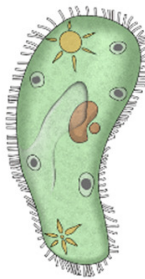

3. Koje strukture u staničnoj građi trepetljikaša ste se po prvi puta upoznali upravo na današnjem praktikumu (tj. za koje strukture papučice ranije niste znali)? (NAPIŠITE S OBZIROM NA OSOBNA ISKUSTVA)

4. Je li vam bilo teško pratiti današnje vježbe s papučicom? Obavezno navedite zašto (NAPIŠITE S OBZIROM NA OSOBNA ISKUSTVA)

5. Zašto vam se je/nije svidio način rada s današnjeg praktikuma? (NAPIŠITE S OBZIROM NA OSOBNA ISKUSTVA)

Prilog 3 Primjeri odgovora studenata učiteljskog fakulteta (SU) i studenata biologije (SB) na peto pitanje upitnika (Zašto vam se je ili nije svidio način rada $s$ današnjeg praktikuma?)

\section{Oznaka Odgovor ispitanika}

SB_1 Lakše je tražiti ono što treba uočiti, no možda se ovakvim samostalnim donošenjem zaključaka bolje zapamte određene činjenice.

SB_2 Zato što prilikom prethodnog pojašnjenja tražim samo određene strukture koje su mi zadane za pronaći i ne razmišljam o široj slici niti tražim sama objašnjenja, dakle moje razmišljanje je svedeno na minimum, a takav način obrazovanja je loš. Posebice u području znanosti gdje ćemo jednog dana živjeti od donošenja zaključaka iz vlastitih promatranja nečega.

SB_3 Svidio mi se način jer smo sami morali donositi zaključke o onome što vidimo na preparatu.

SB_4 Svidio mi se, ali malo je lakše kada smo prethodno upozoreni na točno određene strukture na koje trebamo obratiti pažnju jer ih ovako možda ne opazimo dovoljno dobro.

SB_5 Današnji praktikum mi se svidio, jer sam sama razmišljala više o onome što gledam, uočila sam samostalno više detalja, ali jednako tako mi se sviđa i promatranje nakon prethodnog pojašnjenja. Obje metode su dobre i mislim da se nadopunjuju te da bi obje bilo dobro koristiti.

SB_6 $\quad$ Svidjelo mi se jer smo prethodno naučili gradivo zbog ispita. Više volim promatrati nakon prethodnog pojašnjenja jer onda znam na šta trebam obratiti više pažnje i lakše razumijem protumačeno gradivo nakon što zapravo i vidim o čemu sam učila.

SB_7 Današnji način rada mi se svidio jer smo od prije upoznati s temom pa nije bilo teško pratiti praktikum i bez prethodnog

objašnjavanja struktura unaprijed. Inače, ako nismo upoznati s temom, preferiram pojašnjenje prije izrade i gledanja preparata.

SB_8 Svidio mi se način takvog promatranja jer je zanimljiv i smatram da mnogo možemo naučit iz ovakvog načina rada, ali ipak mislim da za takav način rada u većini slučajeva ne bi bilo moguće provesti jer bi bilo prekomplicirano.

SB_9 Jer smo samostalno upoznali što i kako trebamo radit. Te vidimo na što trebamo obratiti pozornost prilikom rada s preparatima.

SB_10 S prethodnim znanjem jer bilo lakše obratiti pozornost na bitne detalje.

SB_11 Svidio mi se ovakav način rada jer sam radila svojim tempom i više sam razmišljala o tome što radim pa sam lakše i upamtila neke činjenice o trepetljikašima. 
SB_12 Ovako je to učenje otkrivanjem, a ne samo potvrda onoga što nam je već rečeno. Uvijek je zanimljivije nešto sam "otkriti". Lakše je ako već znamo osnove, ali moramo zaključiti pojedine detalje.

SB_13 Preumoran sam bio za samostalan rad.

Svidjela mi se slobodna rada na današnjem praktikumu i ležernost pristupa današnjem zadatku. Svatko je imao mogućnost biranja što će raditi i kako će rasporediti vrijeme, a mislim da je to vrlo dobar i zdrav pristup radu. Svidjelo mi se to kaj smo dobili hranu na kraju praktikuma. Nije mi se svidjelo to što u određenim trenutcima nisam znao "što gledam" odnosno na što bi trebao više obratiti pažnju. Neke stvari smo trebali sami zaključiti i mislim da je to dobro, ali više bi mi odgovaralo da smo dobili neke smjernice (npr. uvodni tekst) koji bi nam možda više pomogle u zaključivanju.

SB_14 Nije mi se u potpunosti sviđao zato što promjene na papučici nisu bile intenzivnije i jasnije izražene. Sviđa mi se što nismo imali prethodno objašnjavanje i što smo sami morali uočiti promjene, ali vrlo rado bi htjela nakon svakog preparata i dobiti pojašnjenje, pa da još jednom pogledam kada znam što tražim.

Sviđa mi se: Uočavanje razlika bez prethodnog objašnjenja, individualna potraga i zaključivanje. Ne sviđa mi se: razlike na preparatima nisu intenzivno uočljive, teško je pratiti brze papučice i pitanja su dosta konfuzna.

SB_15 Sviđalo mi se, ali da sama nisam znala o čemu se radi, ne bi mi bilo zanimljivo jer ne bih znala što treba tražiti i na što treba obratiti pozornost. (u odnosu na detalje).

Drago mi je što smo sve radili sami (preparate) i što je bila opuštena atmosfera. Ne sviđa mi se što prethodno nije bilo nekog objašnjenja što u kojem mediju trebamo tražiti, jer mislim da bismo tako bolje našli tražene detalje.

SB_16 Sve u svemu današnji praktikum mi se svidio jer smo radili metodama (bojanjem) koje do tada nismo koristili. Bilo je zanimljivo detaljno promatrati građu papučice, iako bih ipak voljela znati točno što promatramo zbog lakše usporedbe preparata i lakšeg zaključivanja o procesima unutar stanice.

(ZA): Vrlo zanimljivo i poučno. Imamo priliku promotriti isti organizam iz više kuteva. Potiče na zaključivanje. (PROTIV): Nisu dana detaljnija objašnjenja o predmetu promatranja.

SB_17 Sviđa mi se ovakav način rada, ali kao što smo se na praktikumima prethodno "upoznali s papučicom". Odnosno da se prvo upoznam s gradivom pa onda da znamo sami odrediti.

Praktikum mi se svidio, jer na samostalnom radu mislim da dosta toga naučiš, možeš vidjeti koliko toga znaš samostalno raditi i prepoznati. Odnosno upoznaš svoje znanje! Vrlo je bilo zanimljivo. Nemam nikakvih loših primjedbi.

SB_18 Zato jer otprilike znam što gledam tj. tražim u preparata i lakše se pronađe vjerodostojna slika koja to detaljno i jasno prikazuje. (svidjelo mi se...): Samostalni rad, pitanja su jednostavna i brzo se može odgovoriti na njih. (nije mi se svidjelo...): da nismo prethodno imali objašnjenje što tražimo ili barem neki hint. Gotovi preparati papučice s mlijekom i KR-bojom nisu bili jako kvalitetni i dosta papučica nije uopće bilo obojeno.

SB_19 Mnogo se propušta neuvježbanom promatraču. (GOOD): Fleksibilnost u radu, dinamika u radu, jednostavnost, ekonomičnost. (BAD): Nije bilo prethodnog objašnjenja što se promatra.

SB_20 Svidio mi se današnji način bez prethodnog objašnjavanja jer je sve zapravo davno bilo objašnjeno, ali inače mi je draže prvo dobiti objašnjenje što ću gledati i promatrati.

Samostalni rad mi se više sviđa jer imam osjećaj da više naučim.

SB_21 Svidio mi se ovakav način rad sa obzirom da nije bila nepoznata stvar. Međutim kada je nešto totalno novo bolje mi je kada se to prvo objasni.

Svidjelo mi se šta smo morali uložiti malo truda kako bi saznali nešto.

SB 22 Oba pristupa su jednako interesantna i poučna.

Svidio mi se istraživačko samostalni pristup. Nije mi se svidjelo malim dijelom što nisam sigurna što promatram, odnosno sve se bazira na pretpostavkama.

SB_23 Teško je snalaziti se ako prethodno nije objašnjeno.

(DOBRO): Mirno, staloženo, bez prevelikog pritiska. Ugodnija atmosfera. (LOŠE): Ako se ne zna gradivo prije preapstraktno.

SB_24 (+): Samostalan rad, pravljenje preparata. (-): Teško za pretpostaviti koje su strukture u pitanju iz samostalnog promatranja.

SB_25 Jer kada je prethodno objašnjeno lakše je pratiti i uočiti ono na što trebamo obratiti pozornost.

(sviđa mi se): Potiče na individualnost i korištenje dostupnih resursa. (ne sviđa mi se): Mnogo se banalnih pitanja ponavlja pa se čini kao da su nepotrebna.

SB_26 Svidio mi se jer mogu radit svojim tempom, ali nije mi se svidio jer da je neki drugi organizam u pitanju ne bi znala što gledam. loše: Mikroskop ne radi.

SB_27 Svidjelo mi se to što možemo sami nešto procjenjivati i gledati.

SB_28 Ne volim samostalne radove bez prethodnog objašnjenja.

SB_29 Svidjelo mi se jer je potrebno svega nekoliko sekundi da bismo vidjeli nešto strano i to uočili, ali kada prethodno znamo što očekivati možemo više vremena promatrati o čemu se radi, razmišljat zašto je tako građena, prepoznat kako je do toga došlo evolucijski i slično, a ne samo gledat bez razmišljanja i cilja.

SB_30 Jer sami stičemo nova znanja koja nam trajno ostaju i sve shvaćamo bez prevelikog objašnjavanja.

SB_31 Bio je normalan.

SB_32 Zanimljivije je kada ne znamo što očekivati.

SB_33 Sviđa mi se, ali smatram da je bolje promatrati preparat nakon što smo upoznati s njegovom građom i karakteristikama.

SB_34 Svidjelo mi se jer je bilo objašnjeno prije što ćemo promatrati i znali smo što radimo.

SB_35 Svidio mi se jer mogu sam doći do zaključka o prirodi preparata.

SB_36 Lakše se snalazim kad mi je pojašnjeno.

SB_37 Svidjelo mi se zato što tako učimo odmah i to na primjeru (pod mikroskopom) uživo.

SB_38 Nekad i nakon objašnjenja ne znam što vidim ili trebam vidjeti, a kamoli bez.

SB_39 Jer je bilo iznenadno i neočekivano.

SB_40 Jer je lakše uočiti stvari koje znam da trebaju biti tamo nego da sama pokušavam "pogoditi" što je i jasnije je i lakše za zapamtit podatke ako je prije toga objašnjeno.

SB_41 Nije mi se svidio jer nije bilo prethodno objašnjeno.

SB_42 Znamo što približno moramo tražiti. 


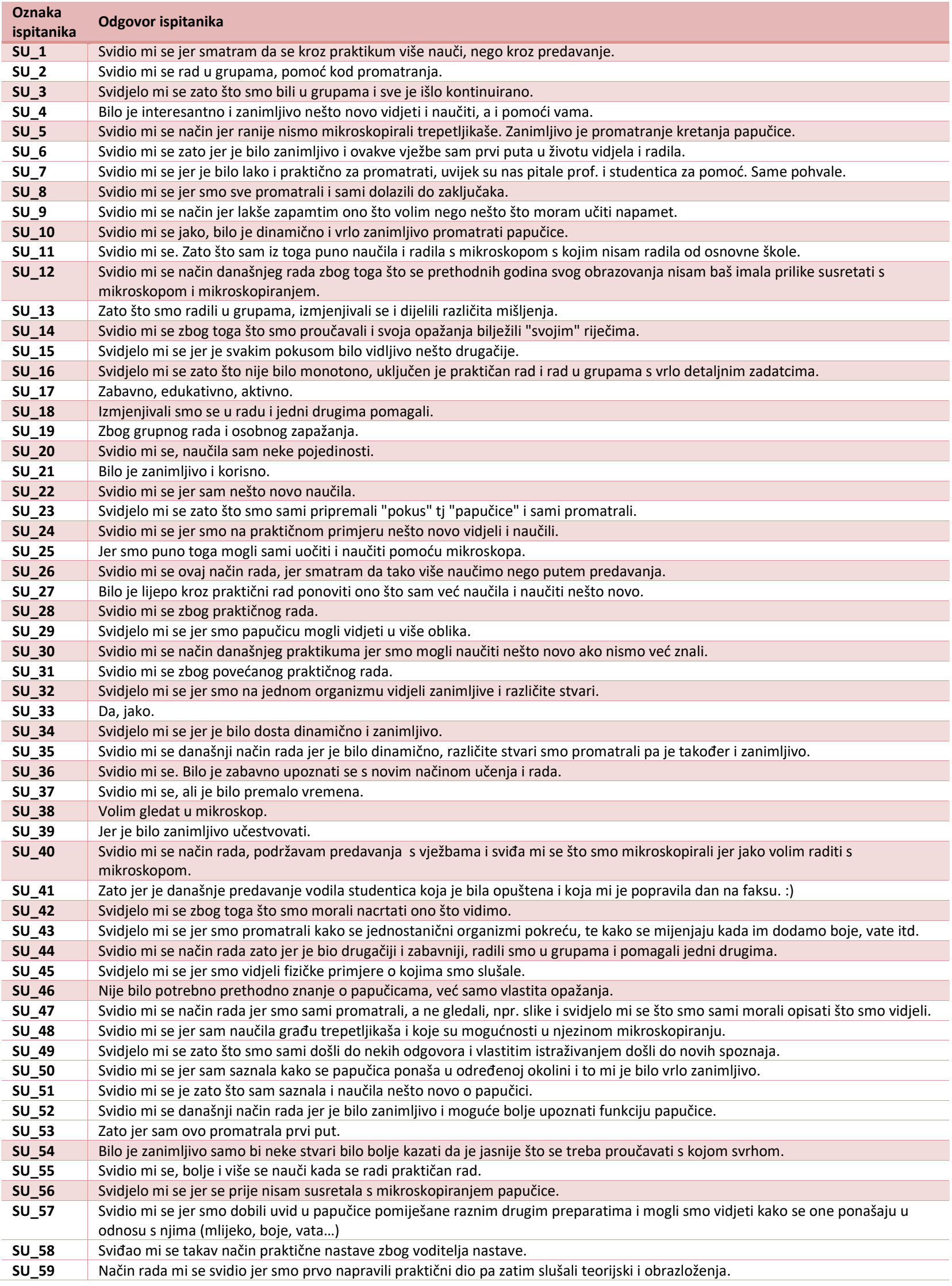




\title{
Application of active learning based on observation and recording observations - example of microscoping Paramecium sp.
}

\author{
Mirela Sertić Perić1, Ana Marija Matić1, Darinka Kiš-Novak², Goran Vignjevićc ${ }^{3}$,Irena Labak ${ }^{3}$ \\ ${ }^{1}$ University of Zagreb, Faculty of science, Department of biology, Zagreb, Croatia \\ mirela.sertic.peric@biol.pmf.hr \\ 2 University of Zagreb, Faculty of Teacher Education, Čakovec Branch, Čakovec, Hrvatska \\ 3 Josip Juraj Strossmayer University of Osijek, Department of biology, Osijek, Hrvatska
}

\begin{abstract}
The use of active learning methods avoids direct transfer of facts and conclusions, and promotes the acquisition of knowledge through solving challenges and problems. Active learning often involves independent students' investigation, including observing, recording observations, and bringing conclusions based on observations. Such approach increases the intellectual engagement of students as well as the likelihood that the students will successfully apply the acquired knowledge to new challenges in the work environment or in other life situations. The effectiveness of active learning methods, among other things, often depends on the context of the problem presented to students and on the interest of students for particular learning activities. This paper presents an example of the application of active learning methods including the activities of observing and recording observations during microscoping various biological preparations of Paramecium sp. We present the worksheet, which can be used as a basis for planning and adapting teaching activities at other education levels, but also the students' comments following the implementation of the active learning methods. Students' comments on the use of active learning methods (as opposed to traditional teaching methods, which are commonly used within the students' lab lessons), provide an insight into the impression students have gained regarding: their general learning experience, active learning methods, and the effect of the applied activities on understanding the learning content. Most students declare that active learning methods are interesting and that they "like such activities" that include working and concluding independently. Such student opinion could serve as certain encouragement for more intensive application of the active learning methods at the faculty education level, and that the active learning methods should gradually replace the existing traditional methods.
\end{abstract}

Keywords: STEM literacy; learning by discovery; observational skills; notes; Protozoa 